\title{
NATURAL DEATH VS CIVIL DEATH
}

\author{
Valbona ALIKAJ \\ bonaaliko@gmai.com
}

D DOI:10.5901/mjss.2014.v5n22p320

\begin{abstract}
Death is an inevitable phenomenon, which implies the termination of the life of persons. All over the world, in a day, a large number of children are born, but unfortunately also a large number of people die because of illness, age, homicide, suicide or poverty. Death is not only a biological process, as at the same time it affects directly the legal capacity of a person. Therefore the natural death of the person is seen as a cause that brings legal consequences at its verification. Being considered as a natural phenomenon as well as legal, death is considered as a legal fact with which legislations bind the beginnings, changes or terminations of legal. Legal capacity of a person, as a condition to undertake rights and obligations, is the determining element to gain the quality of a natural person. This quality is gained with the birth and terminated with the death. There are special cases, under which it is difficult to verify the natural death of a person for reasons such as: absence of the cadaver or the uncertainty of the circumstances in which the person has been lost or absented. In order to guarantee the legal security and also the conservation of personal and property rights of the person, legislations have provided the declaration of the person dead, which may come as a result of natural disasters, accidents, military actions or as a consequence of declaring before the person missing. This paper aims to make a comparative analysis between the procedure of declaration of a natural death of the person and the procedure of declaring a person dead according to the Albanian legislation. For this reason it will be analyzed the persons who are entitled to make the request for the declaration of the person dead, the legal force of the decision of the court through which the person is declared dead and the necessary time limits for declaring a person dead.
\end{abstract}

Keywords: natural death, civil death, procedure, legitimated persons, declaration of death

\section{Introduction}

Death is the phenomenon of the termination of physiological functions of creatures, including humans. Death as a philosophical concept is "the termination of life on earth, the separation of the soul from the body. The death of the person is the body's death, passing into the afterlife, in that spiritual..." (Dalya, 1881).

Death as a biological concept is the termination of life (Ozhegov, 1953).

Death is a legal fact, categorized as a natural event which occupies a special position among other legal facts. This is not only linked with the psychological influence of relatives but, at the same time it directly affects on the legal capacity of a person. Natural death of the person brings the termination of some legal consequences and the beginning of some others.

The dead person ends his biologically life, but he continues to remain part of some juridical consequences, because from the juridical point of view it is considered as a legal fact which entails the beginning, the changes or the termination of legal relations.

Death is a fact that brings the acquisition of rights and obligations for a group of people. Some legal relationships begin with the verification of death as; property rights and obligations which exceed by the inheritance to the heirs. Instead, some other relationships terminate as the dissolution of the marriage (Art. 123 Family Code of Albania)

Beside the natural death of the person, which is due to the termination of all its physiological functions, legislations provide even the civil death, which presumes a possible natural death.

As in the case of natural death, even the civil death must be registered in the state civil authorities.

There are two ways by which a person can be declared dead

natural death, which is certified on a medical report;

Civil death which is verified by the court decision which recognizes the person dead (Art. 379 Procedural Code of Albania):

a. if for over six years there have been no news from the date of receiving the latest news from the person 
b. if the person has been lost during military actions and this missing is verified by military authorities, when there is no notice for two years issuing certified by the competent military authorities, when there is no notice for two years from the peace establishing agreement has entered into force or three years from the end of military actions

The person missing during a natural disaster or in circumstances which appear to show he is deceased, may be declared deceased by decision of the court, when there have been no notices from him for two years after the disaster has occurred, without necessarily being previously declared missing (Art. 19 Civil Code of Albania);

This paper aims to analyze the relevant procedures for each of the ways of declaring a person dead and the legal relations that begin, change or terminate as a result of this declaration .

\section{NATURAL DEATH AND THE REGISTRATION IN THE CIVIL REGISTRY}

The Civil registry the set of personal data of Albanian citizens, foreign citizens and stateless persons who are temporarily or permanently resident in the Republic of Albania and which are registered and kept in the National Civil Registry and which help to certify the birth, the existence, the individuality and the relationships between them (Art. 2/1Law "Civil State").

The Civil registry the set of personal data, that verify the birth, existence, individuality of the citizens and their relations. These facts are to a particular importance because they serve to identify the person and determine relationships between them.

These facts are of a particular importance because they serve to identify a physical person and to determine the relationship between him and the others.

The registration in civil registry is also important for acquisition of the rights and obligations of the person. Registration of legal facts in the civil registry determines the juridical status of the person in a certain moment, beginning from his legal capacity, the capacity to act and his rights and obligations.

The components of the civil registry are: name and surname, identity number, date of birth, place of birth, sex, nationality, motherhood, fatherhood, marital status, death, declaration of missing, residence, domicile and other facts provided by law (Art. 6 "Civil State").

One of the main components of the civil registry is death. The act of registration of death brings the termination of legal capacity of a person and the beginning of legal consequences for relatives and other persons who have been in a legal relationship with the deceased.

\section{The procedure of the declaration the natural death}

The Albanian Law no. 10129, dated 11.05.2009 "On the Civil Registry" provides the declaration of a natural death. Respectively article 52 of this law provides that the declaration of death can be made by any adult family member or a relative of the family and, in their absence, from the compliance officer of the municipality/ commune, in the Civil Registry Office, where the citizen had the domicile/ residence or where the body was found.

The citizen is determined as dead, when his death is verified by a medical report, through which is identified the person and determined the time, place and cause of death.

When the body can not be identified, or when suspected signs of a violent death are observed the report issued by the forensic expert should be signed by the prosecutor.

In the medical report the causes of death are classified due to health, accidental or criminal reasons. The declaration of death should be made within 10 days of the incident, or the finding of the body of the dead person, and within 60 days, when death has occurred abroad (Art.52 Law "Civil State").. For those who die in hospitals, military bases, in prisons, in rehabilitation wards and other institutions are obliged to inform in written form the nearest office of civil registry within 5 days, for deaths occurring in their institutions. With the declaration of death, the civil registry office gives the funeral permission.

In the communes who are under the jurisdiction of municipalities where there are not registry office the funeral permission is given by the mayor of the commune. In this case, the mayor of the commune, after the administration of the documents that verify the death, is obligated within five days, to notify the civil state office where the citizen was registered, for the registration of the death certificate. 
When the civil state office takes the notification of death, from the above institutions and in cases when there are no relatives to make the declaration, it requires the verification from the representatives of the local government. If the death is confirmed, then he compiles the act of death, which must be signed, as appropriate, from the representatives of the local government, the mayor of the commune, the district administrator, or from the representatives of the funeral service, or the representative.

The death certificate will be absolutely void when the person, in fact, is not dead, which is confirmed by his physical appearance or his existence after the date of the act of death, in cases of the absence of the body or when the body results of another person (Art. 55 Law "Civil State").

\section{THE PROCEDURE OF DEATH RECOGNITION BY A COURT DECISION}

The recognition of death can be made only by a court decision as it is based not on the fact of the physical death, but on its presumption due to the absence of the person from his last residence and the absents of news for a certain period. Differently from the natural death of the person, in the cases of recognition of death, is impossible to find the body, so the court follows a certain procedure for recognition of death of the person. The court before giving the final decision must respect the time limits provided by the legislation.

\section{The Procedure of recognition of death}

The Albanian legislation based on various circumstances defines three cases of recognition of death. These cases are under the same procedure but they distinguish on the time limits.

The first case, is the recognition of death of the person after he was declared missing, " The person who has disappeared from his residence or his last residing place and from whom there are no news for more than two years, then by the request of any interested person he can be declared missing by the decision of the court." According to this definition the court declared missing the person, after receiving the request made by interested persons. During the trial, the court makes the verification of all the circumstances which make credible the declaration a person missing.

Article 17 of the Civil Code of the Republic of Albania provides, " A person declared missing, upon the request of each concerned person may be declared deceased by a court decision if for four years there have been no news from the date the person is declared missing"

The interested persons who are legitimized to apply upon a request for recognizing a person dead are the same persons who are legitimized for declaring a person missing. After receiving the request, the court within 10 days from her presentation sends a copy to the commune or municipality where the person required to be recognized dead had his last residence.

The commune or municipality is obliged to publish the request in visible places. This request should be also published in local or national newspapers, as well as in the Official Journal.

The judicial process can't be made without passing 6 months from the publication of the request in the Official Journal. This time limit is established with the aim of getting informed the interested persons starting from the own person who is required to be declared missing, his relatives and other persons with whom the person may have entered into legal relations.

During the process, the court should interrogates the relatives of the person, should takes data from the municipality or commune where he had his last residence or his last domicile. The court must conduct a full and universally judicial investigation, in accordance with the law. After the end of the juridical investigation the court takes the decision for the recognition of a person dead.

The court should order the publication of the decision in the Official Journal or at least in one local newspaper assigned by her, or in another way of publication that would be useful (Art. 380 Procedural Civil Code of Albania). The decision of the court should be sent for registration to the respective civil registry in order to register him in the Register of Deaths.

In the two other cases of the civil death, the court can declare the person deceased without declaring him missing. In cases where it considers the specific circumstances of the disappearance of the person provided by law as they can be the disappearance during a natural disaster or in other circumstances or in circumstances which appear to show he is deceased, or in cases of lost during military actions (Art. 19 Civil Code of Albania) and such last is certified by the militaries 
authorities, without having previously declared missing according to the legal time limits (Art. 18 C.C of Albania). The time limits are shorter this time as the possibility that the person is be dead is more convincing.

In both these cases, it is necessary the verification of the facts which can prove the death of the person. In the interpretation of two dispositions the circumstances that lead to the creation of the court conviction for the death of the person are not exhaustive and should be estimated case by case.

The Law of "Civil Emergency" No. 8756, dated 26.3.2001 provides as natural disasters "earthquakes, floods, prolonged atmospheric droughts, architectural mudslides, avalanches, strong winds, forest fires and in residential environments, massive diseases infectious, the consequences of which affect people, livestock, property, environment, and other events caused by natural phenomena. " ( Art. 2/3 Law "Civil Emergency").

Circumstances which make to believe that the person has died and that can be considered by the court are also situation provided by the same law as "other disasters" like "accidents, rail, sea, air, and fire, explosions, falls and dams, nuclear accidents, industrial and ecological or any other accident caused by human action, from war or emergency situations, as well as other forms of mass violence "that are more possible and more common to happen.

Military actions are provided also as one of the circumstances which can bring to the conviction that the person has dead. According to the Law "For the powers and authorities of command and strategic direction of the armed forces of the Republic of Albania" No.8671, dated 26.10.2000 the concept of military actions or operations of the armed forces is provided in art 2 as "undertake a military mission, strategic, operational, tactical, preparation, support, service, administrative and human ". Referring to this provision, the concept of "person" is not limited only on the military forces but also it include civil persons in support functions, as also the civilian person who may be lost during these operations.

The time limit for declaring a person dead as a result of lost during a natural disaster or during the military actions is 2 years. But this time limit may be extended up to three years from the end of military actions. It is no deed any procedure for the publication of the request in these cases, and this because of the conviction of the facts (Art. 18 C.C of Albania). The court's decision, which recognizes the person dead be should registered in the National Registry of Civil Status / basic register (archive), without making the declaration of death.

The act of death will be absolutely void when the person, in fact, is not dead, which is confirmed by his physical presence or the existence after the date of the act of death.

\section{LEGAL EFFECTS OF THE DECLARATION OF THE PERSON DEAD AND OF THE RECOGNITION OF DEATH}

Legal effects that come from the recognition of death are equivalent to the effects that come from the declaration of the person dead. The effects that come from the declaration and recognition of a person dead are non-property, personal effects and property effects. Personal non-property rights and property rights which belong to the person declared missing must be preserved and protected by the administrator appointed by the court up to the recognition of death.

These rights must be preserved, not only to protect the heirs interests but also to conserve the legal relations in which the person recognized dead, may have been a party. By recognizing a person dead all the legal relationships in which he has been a party terminates for him. Heirs at the time of opening of the inheritance profit not only rights, but also the obligations. His property rights, as long as they are not closely personal, passed to the heirs of the dead person.

One of these cases is the undertaking contract which is not dissolved by the death of the contractor, except when the contractor was considered indispensable for the performance of the work (Art. 873 C.C of Albania).

A specific form of passing the property rights is the term transfer of these rights as in the case of property rights as part of author rights, which generally retained for a period of 70 years from the date of the recognizing the person dead (Art. 21 Law "The authors rights and the other rights linked to him")

Another property obligation that terminates with the death of the person is the obligation for alimony, which does not pass to the heirs because of his personal character. Other cases where property rights that do not pass to the heirs are that of the testamentary executor and the guardian or administrator due to the personal character of these obligations.

Differently from the property rights which generally pass to heirs, most of the personal rights terminates with the death of a the person. 
Among personal non-property rights it can be mentioned the conservation of authors rights. These are closely relates with the author when he was alive, but even after his death. Only a part of them can pass with inheritance to the heirs of the author, such as the right to challenge the co authorship, the right to challenge the distortion of the name, etc.

Marriage is the typical example of a personal legal relationship which ends with the death of one of the spouses. Death and the recognition of death are provided by the Family Code as a form of marriage termination. Parental responsibility also terminates with the death of the person as when it was created as a result of a natural connection or adoption. Adoption institute provides an exceptional case, when the death of the adoptive candidate does not affect the successful completion of the procedure and the acquisition of the rights from the adopted child (Art. 242 Family Code of Albania).

This happens when adoptive candidate dies before the court decision but after having given his consent for the adoption. This exceptional case seems to be applied only to the natural death and not in cases of civil death.

The registration of the act of death and the person's registration in the register of death bring as a consequence the removing of the person from some public registers like the register of voters or that of tax authorities. Unlike natural death, civil death is accompanied with uncertainty. Although they have same consequences, the legislation provides the possibility of reappearance of the person recognized dead.

When the person declared dead results alive, he or any other concerned person, can bring a request for the annulment of the recognition of death to the court who issued it. When the person declared dead results alive, he is entitled to reclaim his property and all his rights which he enjoys before the recognition of death, which the exception of marriage which he reacquires it again only if the husband/ wife has not signed a new marriage.

\section{CONCLUSIONS}

Death in both cases is a legal fact, which brings the acquisition of rights and obligations for a certain group of people (who may be heirs or other persons who have been in legal relationship with the deceased). Among them, it can be mentioned: the opening of inheritance (heirs acquire not only rights but also obligations), termination of marriage, the right to exercise the guardianship, the succession of procedural right.

Civil death and natural death have same consequences but this does not mean that they are equal institutes. The first is based on the presumption of death therefore in a precarious situation which can be recovered in the future, the second is based the end of all physiological functions of the person, therefore, the situation is sure. Except of the element of stability the two institutes differ in procedural terms.

As an uncertain situation civil death should be declared by the decision of a public body, which according to our legislation is the court. The court decision gives the possibility to open the inheritance, to change the data components of civil registry and for those legal relationship which can be passed by death, it gives the possibility to the persons who have participated in them to require their implementation by the heirs. So the decision of the court is that it equates the consequences of natural and civil death.

However, the uncertain situation continues. This because the person declared dead can reappear. Of course, in such a possibility the legislation provides the restitution of his rights. This opportunity is given to the person that is declared dead as it guarantees the restitution of rights, but on the other hand it makes uncertain the rights acquired by the heirs, given that the latest lose this quality if the person reappears.

Like all other rights end with the termination of legal capacity of the person, even marriage as a closely personal institute terminates with the civil or natural death of the person. In the case of civil death, as a consequence of uncertainty of this situation, the legislation provides the restitution of marriage in case of reappearance of the person when the surviving spouse has not signed a new marriage.

Considering the time limits with which is linked the declaration of death, the absence of the spouse for such a long time can cause the loss of affinity between spouses, thus making marriage to lose its purpose. The Albanian legislation does not provide for any clause of a prior approval from spouses to continue the marriage, so it shall be considered as uninterrupted. Maybe the consent would be favorable for spouses. Such a provision is made by the Russian legislation which requires an application for restoration of the marriage by the spouses (Art. 26 C. C. of Russian Federation).

\section{References}


Ardian Nuni. (2009) E Drejta Civile, 117-134

Petraq Çuri. (2008) E drejta Proceduriale Civile \& Noteria, 240-244

Владимира Даля .(1882) Толковый словарь живаго великорусского языка

Ожегов, Сергей Иванович (1953) Словарь Русского Языка, 679

Civil Code of Albania

Civil Code of Russian Federation

The Procedural Civil Code of Albania

The Family Code of Albania

Law Nr. 8950 "Civil status law" Of Albania

Law No.8671, dated 26.10.2000 "For the powers and authorities of command and strategic direction of the armed forces of the Republic of Albania"

Law No. 8756, dated 26.3.2001"Civil emergency"

The Family Code of Russian Federation 29.12.1995 N 223-\$3

Law Nr. 9380, datet 28.4.2005 "The authors rights and rights related to it" 